\title{
Industrial Debris Management Control
}

\author{
R. Abinethri, T.Vijayan, B.Kalaiselvi
}

\begin{abstract}
Unfriendly changes were made because of the Contaminants got brought contamination into the indigenous habitat. Contamination can appear as synthetic substances or vitality, for example, clamor, warmth or light Pollutants.Dust, flotsam and jetsam, for example, plastic packs, are blown through wind from landfills and different territories. Plastic packs and different types of plastic waste that were disposed of which exhausted in the sea, jeopardizes natural life and fisheries. Thus this paper learns about control of contamination in mechanical condition. [1],[3],[5]
\end{abstract}

Keywords : Pollution, debris, environment and pollutants.

\section{INTRODUCTION}

As of late, the development of little and minimal effort sensors turned out to be monetarily possible. notwithstanding the way that, Industrialization increase the degree of computerization and meanwhile it assembles the air sullying via releasing the unlucky gasses in circumstance specifically in modern levels. So there should be a device to display screen and verify the superior pollutants. The phrases manipulate and watching arecommonly befuddled and utilized synonymously. mechanical best evaluation is an evaluation of the modern pleasant in connection to standard best set by contamination manage board. The components which may influence theenvironment and human well being may be given outstanding consideration.. [19],[20],[21]

The assessment of condition high-quality will display screen the country of water, to offer source to figuring out styles and gives the insights empowering the inspiration of motive powerful connections. To signify modern conditions industrial checking gathers records fromdifferent areas of ventures and at popular interims of time. because of the multifaceted nature of parameters big differenceswere observed amongthevarious ventures. So additionally, the response to modern consequences is additionally highly thing. remote tracking, manage and astute protection is one of the maximum tremendous criteria for reinforcing technique plant accessibility and introduction. Checking has used to determine inclines within the nature of the water, air and soil circumstance and how they're inspired by means of the advent of toxins, and by using waste treatment activity. Even greater beginning overdue, watching has been grasped to evaluate complement or poisonous substance moves discharged to conduits, ground waters, lakes, oceans and soil

Revised Manuscript Received on August 22, 2019.

* Correspondence Author

R.Abinethri, Department of EIE, Bharath Institute of Higher education and research, Tamilnadu, India. Email: abi.eie@bharathuniv.ac.in

T.Vijayan, Department of EIE,Bharath Institute of Higher education and research, Tamilnadu, India. Email: vijayan.eie@bharathuniv.ac.in

B.Kalaiselvi, Department of EIE, Bharath Institute of Higher education and research, Tamilnadu, India. Email: kalaiselvi.eie@bharathuniv.ac.in or transversely over worldwide the factors of confinement. Regardless, it must be visible that mechanical common high-quality is noticeably component structured upon neighborhood conditions. finally it's far most use full for current field. [2 ], [4],[6]

\section{II.MATERIALS AND METHODS}

Watching structures are arranged and executed for social event data on including air and water quality and on landings of pollutions of stress from genuine point sources. The segments of a checking plan commonly join decision of the parameters of concern; the procedure for aggregation and treatment of tests (demonstrating the region, the repeat, sort, and measure of tests, and analyzing equipment); test examination (or, alter locally, on-line watching); and a game plan for reporting the results. Enveloping degrees of pollutions, for instance, significant metals are estimated in air, water, and soil, nearby various parameters, at decided regions and frequencies and using showed equipment and procedures. The objective is to assemble and separate operator tests to convey data for use in the natural organization structure. To ensure commendable enveloping levels, unions of pollutions in nature are envisioned, using models and information on surges from a bit of the critical sullying sources, and are then watched. [7],[9], [11]

\section{RESULTS}

Mechanical checking is the aggregation of information at different zones of organizations and at typical between times of time remembering to give the information which may be utilized to describe current conditions. In light of the multifaceted idea of parameters considerable assortments are found between different endeavors. Moreover, the response to present day impacts is in like manner significantly factor. Remote Monitoring, Control and insightful help is a champion among the most basic criteria for intensifying creation and procedure plant openness. The idea of water, air and soil condition and how it is debased has been moreover checked. [8],[10],[12]

Even more starting late, checking has been endeavored to assess supplement or sullying changes discharged to streams, ground waters, lakes, soil and oceans or transversely over worldwide the points of confinement. Regardless, it shouldbe saw that mechanical biological quality is amazingly factor dependent upon close by conditions[13], [15], [ 17] 


\section{CONCLUSION}

The field of infection investigation and control is extensive and a couple of works has been tried to restrict the issue of cost and popular tests by means of the application of worldwide system for mobile correspondences. For moderating these troubles, advanced GSM structure can be used. The execution and life of the contamination watching and control device can moreover be upgraded through knowing sensors for controlling residue, clamor, smoke, clamminess and various parameters, as such improving the cutting-edge and not unusual habitat. [14],[ 16], [18]

\section{REFERENCES}

[1] Sharma, R.K., Irusapparajan, G. \& Periyaazhagar, D. 2019, "Three-phase symmetric cascading Z-source seven levels multilevel inverter excited by multi carrier sinusoidal pulse width modulation scheme", International Journal of Innovative Technology and Exploring Engineering, vol. 8, no. 10, pp. $4269-4274$

[2] Velavan, R., Bharanidharan, S. \& Sheeba, B. 2019, "EMF pollution Causes, effects and protection", International Journal of Innovative Technology and Exploring Engineering, vol. 8, no. 9 Special Issue 3, pp. 1166-1168.

[3] Saravana, S., Balaji, S., Arulselvi, S. \& John Paul Praveen, A. 2019, "Reliable power quality monitoring and protection system", International Journal of Innovative Technology and Exploring Engineering, vol. 8, no. 9 Special Issue 3, pp. 644-645.

[4] Tamil Selvan, S. \& Sundararajan, M. 2019, "Performance Parameters of 3 Value 8t Cntfet Based Sram Cell Design Using H-Spice", International Journal of Recent Technology and Engineering, vol. 8, no. 2 Special issue 5, pp. 22-27.

[5] Jac Fredo, A.R., Abilash, R.S., Femi, R., Mythili, A. \& Kumar, C.S 2019, "Classification of damages in composite images using Zernike moments and support vector machines", Composites Part B: Engineering, vol. 168 , pp. $77-86$.

[6] Kathiravan, P. \& Govindaraju, C. 2019, "Design and evaluation of ultra gain isolated DC-DC converter for photovoltaic system", International Journal of Engineering and Advanced Technology, vol. 8, no. 5, pp. 2646-2651.

[7] Kripa, N., Vasuki, R. \& Kishore Kanna, R. 2019, "Realtime neural interface controlled au-pair BIMA bot", International Journal of Recent Technology and Engineering, vol. 8, no. 1, pp. 992-994.

[8] Mohanraj, Meenaa Kumari, M., Philomina, S. \& Jasmin, M. 2019, "In-situ humidity measurement of hydrogen fuel cell car using MEMS sensor", International Journal of Recent Technology and Engineering, vol. 8, no. 1, pp. 41-43.

[9] Velmurugan, T. \& Prakash, S. 2019, "Artificial intelligent based distribution automation of swift fault detection isolation and power restoration for HT network", International Journal of Innovative Technology and Exploring Engineering, vol. 8, no. 6, pp. 1-6.

[10] Dwarakesh, K. \& Prem Kumar, G. 2019, "Five-level inverter based sequential boost system using fuzzy logic controller", International Journal of Innovative Technology and Exploring Engineering, vol. 8, no. 6, pp. 12-19.

[11] Anne Gifta, A. \& Hemavathi, G. 2019, "Analysis of grid tied solar PV system using ANFIS Algorithm", International Journal of Innovative Technology and Exploring Engineering, vol. 8, no. 6, pp. 312-316.

[12] Jayavel, R., Rangaswamy, T.R. \& Prakash, S. 2019, "Efficient grid management system with renewable and conventional power sources", International Journal of Innovative Technology and Exploring Engineering, vol. 8, no. 6, pp. 287-289.

[13] Hemavathi, G. \& Maheshwaran, S. 2019, "Proportional resonan controlled high gain step-up converter system with improved response", International Journal of Innovative Technology and Exploring Engineering, vol. 8, no. 6, pp. 317-323.

[14] Periyaazhagar, D. \& Irusapparajan, G. 2019, "Design and completion of asymmetric single phase 27 level cascaded mli for various pwm scheme", International Journal of Innovative Technology and Exploring Engineering, vol. 8, no. 6, pp. 792-797.

[15] Mahalakshmi, V. \& Vijayaragavan, S.P. 2019, "PV based power electronic converters for high voltage DC applications", International Journal of Recent Technology and Engineering, vol. 7, no. 6, pp. 670-674.

[16] Irusapparajan, G., Periyaazhagar, D., Prabaharan, N. \& Rini Ann Jerin, A 2019, "Experimental verification of trinary DC source cascaded h-bridge multilevel inverter using unipolar pulse width modulation", Automatika, vol. 60 , no. 1 , pp. $19-27$.
[17] Sangeetha, G., Sherine, S., Arputharaju, K. \& Prakash, S. 2019, "On Line Monitoring of Higher Rated Alternator using Automated Generator Capability Curve Administer", Proceedings of the IEEE International Conference on \&amp;quot;Recent Trends in Electrical, Control and Communication\&amp;quot;, RTECC 2018, pp. 176.

[18] Bycil, V.J. \& Wiselin, M.C.J. 2019, "Modeling and analysis of vibration energy harvesting system using piezo stack", International Journal of Mechanical and Production Engineering Research and Development, vol. 9, no. Special Issue 1, pp. 523-533.

[19] Sripada, A., Warrier, A., Kapoor, A., Gaur, H. \& Hemalatha, B. 2018, "Dynamic lateral balance of humanoid robots on unstable surfaces", International Conference on Electrical, Electronics, Communication Computer Technologies and Optimization Techniques, ICEECCOT 2017, pp. 539.

[20] Srinivasan, S., Thirumalaivasan, K. \& Sivakumaran, T.S. 2018, "Performance evaluation of double-output luo converters", Journal of Advanced Research in Dynamical and Control Systems, vol. 10, no. 10 Special Issue, pp. 870-878.

[21] Karthikayen, A. \& Selvakumar Raja, S. 2018, "A skellam distribution inspired trust factor-based selfish node detection technique in MANETs", Journal of Advanced Research in Dynamical and Control Systems, vol. 10, no. 13 , pp. $940-949$

\section{AUTHORS PROFILE}

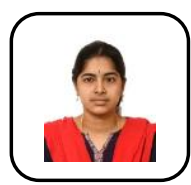

R.Abinethri, Assistant Professor, Department of EIE,Bharath Institute of Higher education and research, Tamilnadu, India

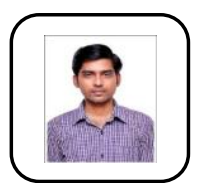

T.Vijayan, Assistant Professor, Department of EIE,Bharath Institute of Higher education and research, Tamilnadu, India.

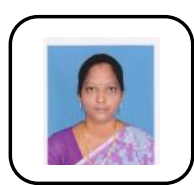

B.Kalaiselvi, Assistant Professor, Department of EIE,Bharath Institute of Higher education and research, Tamilnadu, India 